\title{
Etkileşimli Medya ve Öğretim Ortamlarında Tasarım Geliştirme Süreci
}

\author{
Arş. Gör. Banu Bulduk
}

\section{Öz}

$\mathrm{Bu}$ makalede, etkileşimli medya/çoklu ortam uygulamalarının tasarım geliştirme süreci Çoklu Ortam Tasarım IIlkeleri kapsamında incelenmektedir. Etkileşimli medya uygulamaları geliştirilirken söz konusu ilkeler ve etkisinin incelenmesi, araştırmanın yöntemini belirlemektedir. Bu araştırma, çoklu ortam uygulamalarının tasarım geliştirme sürecinin önemini ortaya koymaya yönelik olup, nitelikli çoklu ortam uygulamalarının tasarım süreci makalenin sınırlıı̆̆ını oluşturmaktadır. Bu kapsamda konunun daha anlaşılır kılınabilmesi için öğretim materyallerinden örnekler, söz konusu ilkeler kapsamında incelenmektedir. Sonuç olarak, uygulamaların nitelikli bir süreç içerisinde tamamlanması ve değerlendirilmesi için sürecin programlanması önerilmektedir. Görsel tasarım ve çoklu ortam tasarım ilkelerinin, etkileşimli medya uygulamalarının nitelikli ürün geliştirme sürecinde önem taşıdığı sonucuna varılmaktadır.

Anahtar Kelimeler: Çoklu Ortam, Çoklu Ortam Tasarımı, Etkileşimli Medya, Etkileşimli Öğretim Ortamı, Çoklu Ortam Tasarım Illkeleri.

\section{DESIGN DEVELOPMENT PROCESS IN INTERACTIVE MEDIA AND LEARNING ENVIRONMENTS}

\section{Abstract}

In this article, the design process of interactive media/multimedia applications is discussed in terms of Multimedia Design Principles. While interactive media applications are being developed, these principles and the study of its effect formed the method of the research. As well as this research's being about revealing the importance of the design development process of multimedia applications, qualified design depelopment process of multimedia applications forms the limitedness of this article. Within this framework, the samples of teaching materials are studied in terms of the principles in order to make the subject clearer. Consequently, that the process should be programmed is recommended to complete and evaluate the applications in a qualified process. It is concluded that visual design and multimedia principles matter to qualified product development process of interactive media applications.

Keywords: Multimedia, Multimedia Design, Interactive Media, Interactive Learning Environment, Multimedia Design Principles. 


\section{Giriş}

Bilgiye erişme yolları, bilgi ve iletişim teknolojileri aracılığıyla genişlemekte ve günlük yaşamda kullanılan öğretim kaynaklarını/materyallerini çeşitlendirmektedir. Öğrenme deneyimi de, söz konusu kaynaklar aracılığı ile kişiden kişiye göre değişmektedir. Çoklu ortamla öğrenme, iletinin birden fazla duyuya aynı anda hitap ederek hedefe iletimini sağlayan bir yol olmaktadır. Öyle ki çoklu ortam (multimedia) kavramı, birden fazla duyuya aynı anda hitap etme olarak tanımlanmaktadır. Öğretim boyutunu anlama ve iyileştirme ile ilgili olan öğretim tasarımı, öğretimin niteliğini arttırmak için öğretim kuramlarının kullandığı bir bilgi disiplini olarak tanımlanmaktadır (Fer, 2011: 13). Bir başka ifadeyle çoklu ortam, "öğretim sisteminin merkezinde bilgisayarların yer aldığı ve öğretimin birbirini tamamlayan tümleşik kaynaklarla sunularak öğrencinin etken kılındığı eğitsel bir uygulama" olarak ifade edilmektedir (Kuzu, 2014: 3). "Bilginin sözcükler ve resimlerin birleşimi olarak sunulması" olan çoklu ortam (Perkmen, 2009: 57), etkili öğrenme sürecinde öğrenilenlerin daha kalıcı olması ile eş anlamlıdır. Öğrenilenleri hatırlama oranları da, söz konusu duyuların kalıcı bellekte yer edinmesine etki oranlarına göre farklılaşmaktadır. Örneğin, görerek hatırlananlar yüzde 30'luk bir dilim iken, hem işitip hem görerek hatırlananlar yüzde 50, görerek öğrenilenler ise yüzde $83^{\prime}$ lük bir dilimi işaret etmektedir (Perkmen, 2009: 19). Bu durum, görsellerin, bireylerin öğrenme düzeyleri üzerindeki rolünü belirgin kılmaktadır. Bu konuda çeşitli araştırmalar, görsel ögelerin ve betimlemelerin öğrenenlerin kavramları somutlaştırma, anlamlarını çıkarma, bilginin iletimini kolaylaştırma ve kavramlar arası bağlantı kurmasını sağlama açısından etkili olduğunu söylemektedir. Görselleştirme, içeriğin somutlaştırılması açısından daha açık hale gelmesine katkıda bulunmakta, daha somut hale gelen içeriğin ise öğrenmeyi kolaylaştırdığı ifade edilmektedir (Tezci, 2011: 16). Bu makalede, çoklu ortam uygulamalarının kişilerin öğrenme düzeylerine etkisi, algıyı ve öğrenmeyi kolaylaştırıı ilkeler çerçevesinde incelenmektedir. Araştırma, öncelikle öğretim materyallerinden çoklu ortam uygulamalarının, nitelikli ve işlevsel özellik taşıması gerekliliği çerçevesindedir. Etkileşimli öğretim ortamlarının belirlenmesi, kullanıcı hareketlerinin gözlemlenmesi, uygulamaların tasarımlarının incelenmesi ve sorunların belirlenmesi öncelikle araştırmanın kapsamı içerisindedir. Bireylerin algılarını etkileyip yönlendirdiği düşünülen görsel tasarım ve çoklu ortam ilkeleri, makalenin yöntemini şekillendirmektedir. Etkileşimli medya uygulamalarının söz konusu ilkeler gözetilerek incelenmesi, kullanıcıların uygulamayı kullanabilme ve algılayabilme düzeyleri, uygulama örnekleri arasında başarı ölçümü yapabilmeyi olanaklı kılmıştır. Kullanıcının/okuyucunun etkinliği, uygulama içerisindeki dolaşım hız ve öğrenme deneyiminin verimliliği, 
söz konusu ölçümün değerlendirme aşamalarındandır. Eğitimde teknoloji entegrasyonu göz önünde tutularak, çoklu ortam materyalinin tasarım süreci detaylandırılarak, konu edinilmektedir.

\section{Çoklu Ortam, Öğrenme Deneyimi ve Görsel Algı}

Çoklu ortam kavramını açıklayıcı çok sayıda tanımlamalar yapılmıştır. Amerikan eğitim psikoloğu ve Kaliforniya Üniversitesi'nde profesör olarak görev yapan Mayer'e göre, çoklu ortam "sözcüklerin ve görsellerin sunum materyallerinde kullanılması" anlamına gelmektedir (2001: 2). Öğrenme, her geçen gün gelişen teknoloji ve araçlar ile biçim ve ortam değiştirmektedir. Senemoğlu, öğrenmeyi "Bireyin çevresiyle belli bir düzeydeki etkileşimleri sonucunda meydana gelen nispeten kalıc izli davranış değişmesi" olarak tanımlamaktadır (2010: 4). Bilgi ve iletişim teknolojileri, çoklu ortam uygulamalarını etkili ve verimli bir öğrenmenin gerçekleştirilebilmesi için değiştirmekte, teknoloji aracılığıyla yeni ortamlarda öğretim materyalleri tasarlanmaktadır. Böylelikle çoklu ortam tasarım ürünleri, eğitim ortamlarında kullanılır hale gelmektedir. Bilgisayar teknolojisi, bireylerin çevresiyle etkileşime geçmesi bağlamında rol alan araçlar olmaktadır. Öyle ki bilgisayar ve programları aracılığı ile öğrenmeyi gerçekleştirdikleri, öğrenci - bilgisayar etkileşimli bir öğretim biçimi olarak ifade edilir. Öğretim tasarımı ise, öğrenenin bilgiyi edindiği çoklu ortam tasarım aracı olarak tanımlanabilir. Akbulut'a göre, "Eğitsel gereksinimleri karşılamak ve öğrenme deneyimlerinin kalitesini arttırmak amacıyla etkili öğrenme sistemleri, geliştirmeyi gerektiren bir süreç" diye düşünülürse (2014: 38), öğrenmeyi etkin hale getirmek, görsel tasarımın sorumluluğundadır. Görsel tasarım, mesajın hedef kitleye iletiminde etkinliğini arttırıcı araç olarak tanımlanmaktadır. Kişilerin, nesneler arası iletişimini sağlayan görsel algı kavramı da bu bağlamda önem kazanmaktadır. Görsel algı, plastik sanatlar/görsel sanatlar öğretiminde önemli bir yerdedir. Öyle ki algısal deneyimler, bilgi edinmenin önemli bir aracı olarak görülmektedir. Kişi, görme, dokunma, duyma, tat alma ve koklama duyuları ile çevreden çok sayıda bilgi almaktadır (Tuna, 2009: 149). Cüceloğlu, algıyı duyudan farklı olarak nitelendirmektedir. Algılama anında insan beyni, bireyin içinde bulunduğu durumdan beklentilerini, geçmiş yaşantılarını, diğer duyu organlarından gelen farklı duyuları ve toplumsal ve kültürel farklı etkenleri hesaba katarak gelen duyulara anlam verme eylemini gerçekleştirir. Duyu organları, insan beynine basit duyuları iletirken, algılama, bireyin geçmiş öğrenme ve deneyimini de katan karmaşık bir süreç geliştirir (2013: 118-119). Bu nedenle, tasarımlarda kullanılan her bir ögenin anlam, boyut, içerik ve konumu bu bağlamda bireylerin algı becerilerini etkileyen ögeler olmaktadır. Bu sebeple algının, 
kendisini oluşturan duyusal girdilerin toplamından fazla bir anlam ifade ettiğini ilk, Alman psikologları Gestalt kelimesi ile ifade etmiştir. Gestalt Illkeleri, bireylerin görsel düzenlemeleri algılama şekilleriyle ilgilenir. Algı düzeylerini etkileyen Gestalt ilkeleri, bireylerin algılama sistemlerinin şekil ve zemin arasındaki ayrımı algılaması, şekil-zemin (figure-ground) ilkesi, organizmanın tamamlanmamış biçimleri, şekilleri ve sesleri tamamlayarak algılaması tamamlama (closure) ilkesi, aynı yönde giden çizgi, nokta vb. şekillerin birlikte gruplanarak algılanması devamlılık (continuity) ilkesi, organizmanın bir alandaki ögeleri, nesneleri birbirlerine olan yakınlıklarına göre gruplandırarak algılama eğiliminde olması yakınlık (proximity) ilkesi, bireyin basit, düzenli bir şekilde organize edilmiş figürleri algılaması basitlik (simplicity) ve şekil, doku, renk, biçim, cinsiyet, vb. özellikleri ile birbirlerine benzer maddelerin birlikte gruplandırılarak algılanması benzerlik (similarity) ilkesi olarak sıralanmakta ve tanımlanmaktadır (Cüceloğlu, 2013: 123-125; Senemoğlu, 2010: 243-247). Gestalt kuramına göre algı bir örgütlenme/bir araya gelme/bilgiye temel olan ve onu oluşturan bütün olarak tanımlanır. Kuramın geliştiricilerinden $M$. Wertheimer, belli uyarıcıların bir arada nasıl kullanılmasını, yapılaştırılmasını ve yorumlanmasını belirleyen söz konusu ilkeler ile her algının biçim olarak gelişen bir bütünü oluşturduğunu ifade eder (Tuna, 2009: 150). Biçim, şekil, form, parçaların toplamından ziyade bütün anlamına gelen Gestalt kelimesi, kuramcılara göre "Bütün, parçaların toplamından daha fazladır ve birey, bütünü parçalarına ayrıştırarak değil, bütünlük içinde algılar" (Senemoğlu, 2010: 240). Bir grafik ürünün de birçok ögeden (tasarım ögesinden) oluşması, ancak bir bütün olarak algılanması bu duruma örnek gösterilebilir. T.F. Uçar, Gestalt felsefesini bir grafik tasarımcı gözüyle şöyle ifade etmektedir: "Gestalt felsefesini bilmek, grafik tasarımcıya hedef kitlenin algı boyutuna göre tasarım üretebilmek açısından değerli veriler sunar." (2004: 65). Görsel iletişim tasarımı açısından algılama ilkeleri olarak adlandırılabilen Görsel algı bağlamında Gestalt Illkeleri, grafik tasarım uygulamalarında mesajı taşıyan ve onu organize eden kavram çerçevesinde hedefe ulaşan bir ürün olarak şekil bulmaktadır. Öyle ki çoklu ortam tasarım uygulamalarında da algıyı kolaylaştırmak ve öğrenmeyi gerçekleştirmek amacıyla Mayer'in Çoklu Ortam Tasarım İlkeleri göz önünde tutulmaktadır. İki durumda da bireylerin algı becerilerini, çoklu ortam uygulamalarının tasarımlarının yönlendirmekte olduğu söylenebilir.

\section{Çoklu Ortam Illkeleri ve Tasarım Süreci}

Çoklu ortam tasarımlarında tasarım süreci, görsel tasarım ögelerinin tasarım ilkeleri çerçevesinde düzenlenmesini kapsamaktadır. Uygulamanın hedef kitlesinin belirlenmesi ve analizi, tasarımın amacının oluşturulması ile paralel 
olarak gelişir. Amacın belirlenmesi, uygulamanın tasarımını da etkiler. Çoklu ortam tasarım uygulaması, öncelikle disiplinler arası bir çalışma olarak adlandırılabilir. Uygulamayı yapacak kişilerin, farklı alan uzmanlarından oluşması nedeniyle bir ekip kurulması sürecin başlangıcını oluşturur. Uygulama, proje yürütücüsü, eğitimci, metin yazarı, grafik tasarımcı, yazılımcı vb. ilgili alan uzmanlarından oluşturulan ekip ile gerçekleştirilir. Proje olarak adlandırılan bu uygulamada, iş akış çizelgesi oluşturmak ve proje takvimi çıkarmak sürenin sağlıklı kullanılması açısından yol gösterici olmaktadır. Söz konusu ekip, alanında yetkin ve donanımlı kişiler olarak belirlenmeli, ekibin hızını kesmeyecek nitelikte ve tecrübeli kişiler olması önerilmektedir. Çoklu ortam uygulamaları resimli çocuk kitabı, yetişkinlere yönelik hikâye kitabı, eğitsel e-kitaplar, öğretici oyunlar, bilgilendirici grafikler, yönlendirici ara yüzler ya da tanıııı uygulamalar olarak sayılabilir. Her uygulama için öncelikle bir kavram belirlenmeli, içerik projenin amacına göre hazırlanmalı, konu ile ilgili literatür araştırması gerçekleştirilmeli ve projenin kimliği oluşturulmalıdır. Projenin rotası, temanın belirlenmesi, ana fikrin oluşturulması ile belirlenir. Bir diğer nokta ise uygulamanın hitap edeceği kitlenin belirlenmesidir. Uygulamanın hedefe ulaşabilmesi alt yapısının planlanması ile ilgilidir. Uygulamanın görsel çatısı ise çalışma ekibinde yer alan tasarımcılar tarafından oluşturulur.

İçerik ile ilgili bir görsel kimliğin oluşturulması, projenin işlevselliğini etkilemekte ve bu nedenle önemli bir aşama olarak kabul edilmektedir. Öğrenme ve algılama becerilerini etkileyen Çoklu Ortam Tasarım illkeleri bu aşamada göz önünde bulundurulmalı, algıyı yönlendirici detaylar, öğrenimi kolaylaştırıcı ve dikkati toplayıcı özellikler eklenmelidir. İçeriği oluşturulan ve görsel tasarımı gerçekleştirilen uygulama, yazııı uzmanları ile çalıştırılabilir hale getirilir. Alt yapı planlaması ve görüntüleneceği ortamın belirlenmesi ile kullanııılardan geri dönüşler alınır. Bu şekilde, varsa yazılım çakışmaları ve kullanım hataları giderilir. Kullanılabilirlik testi olarak adlandırılan bu aşama, projenin ön değerlendirme sürecidir. Söz konusu test, uygulamanın daha iyi çalışması, eksikliklerin eklenmesi, varsa çalışmayan özelliklerin giderilmesi ve uygulamanın kullanıcı dostu olarak geliştirilmesi sebebiyle önemli bir aşamadır. Uygulamanın son kullanıcıya erişmesi, projenin iş akışının programlanması ve bu akışa uyulması ile sağlıklı bir şekilde gerçekleştirilmiş olur. Illetişimi yayıncılık sektöründe tek taraflı olmaktan çıkaran etkileşim kavramı, okuyucuları (öğrenenleri) etkinleştiren ve yönlendirip kontrol yetkisi veren çoklu ortam tasarım uygulamalarında kullanılan bir özellik olmaktadır. E-öğrenmenin öğrenci başarı düzeyi üzerindeki etkisinin incelendiği araştırmalar yapılmış, okuyucuyu kullanıcı olarak aktif hale getiren bu özellik hakkında, Roblyer ve Wiencke uzaktan eğitimle verilen derslerde, öğrencilerle etkileşim derecesinin, başarıyı açıklayan önemli bir 
gösterge olduğunu ifade etmiştir (Gülbahar, 2012: 72). Bilgiye ulaşmada geleneksel yöntemlerin değişerek geliştiği şu günlerde, kullanıcının ürün içerisinde dolaşımını, ögeleri hareket ettirebilmesini ve uygulamayı yönlendirebilmesini sağlayan etkileşimli çoklu ortam uygulamaları tercih edilir olmaktadır.

Richard E. Mayer, öğrenmenin bilişsel alt yapısı ve öğrenmeye etkisi üzerinde çalışmı̧̧; çalışan bellek ve öğrenme sürecini göz önünde bulundurmuş ve çoklu ortamda öğrenme sürecinin gerçekleşmesi, çalışan bellekte oluşan bilişsel yükün seviyesinin uygun düzeyde tutulması ve işlenmesi amacıyla çoklu ortamda öğrenme kuramını geliştirmiştir. Bu bağlamda çoklu ortamın ve yeni medya uygulamalarının öğrenmeye etkilerini inceleyerek yol gösterici ilkeler geliştirmiştir. Çünkü çalışan bellek, çoklu ortamda öğrenmenin gerçekleştiği bir alandır. Bu nedenle gereksiz ögelerle aşırı yüklenmiş bilişsel yük, öğrenmeyi olumsuz etkilemektedir. Mayer, 2001 yılında Multimedia Learning adlı kitabında yer verdiği öğrenme sürecini geliştiren ve destekleyen Çoklu Ortam Tasarım Ilkeleri'ne yer vermek gerekirse;

Mayer'in, (1) Çoklu Ortam illkesi, öğrenenlerin yalnızca sözcüklerin kullanılması yerine, görsel öge (çizim, resim, tablo, şekil, fotoğraf, hareketli görüntü vb.) ve sözcüklerin bir arada kullanılması durumunda daha iyi öğrenme gerçekleştireceklerini söyler. Öyle ki, içeriğin yalnızca görsel öge ya da sözcükler ile desteklenerek sunulduğu tasarımlara göre ve sözcük ve görsel ögelerin aynı konuda bütünleştirildiği tasarımlarda öğrenmenin daha iyi gerçekleştirildiği ifade edilmektedir. W. Howard Levie ve Richard Lentz, 1982 yılında yaptığı bir araştırmada, görsel ögeli ve ögesiz metinlerin çocuklar üzerindeki öğrenme ve algılama düzeylerini test etmişlerdir. 55 deney araştırmasının değerlendirilmesi ise resimli ve resimsiz metinlerin karşılaştırılması ile yapılmışıı. Araştırmanın sonuca göre \%98 oranla, resimlemesi ile beraber sunulan metinlerin resimsiz metine göre daha iyi ve etkili öğrenildiği sonucuna ulaşılmıştır (Levie \& Lentz, 1982). ${ }^{1}$ Bu durum, görsel ögelerin bireylerin metinleri algılama ve öğrenme becerilerine katkısını destekler niteliktedir. Metinlerin bireyler tarafından daha tutarlı ve doğru hatırlandığı konu ile ilgili yapılan diğer araştırmaların da ortak bir sonucudur. (2) Birliktelik illkesi, öğrenenlerin birbirleri ile ilgili görsel öge ve sözcüklerin aynı sayfada ya da ekranda konumsal ve zamansal anlamda yakın olarak yerleştirilmesi ile daha iyi öğrenileceğini kapsar. Bu şekilde birbirleri ile ilgili görsel öge ve sözcüklerin sayfada veya ekranda yakın

'Levie, W.H., Lentz, R. (1982). Effects of Text Illustrations: A Review of Research. ECTJ, 30(4), s. (I95-232), Web: http://link.springer.com/article//0.1007\%2FBF02765 /84\#page- adresinden 05 Mayıs 2015'te alınmıştır. 
olarak konumlandırımasının, uzak olarak konumlandırıldığı durumlara göre daha etkili olacağına işaret edilir (Clark ve Mayer, 2003: 70). (3) Tutarlıık (Özlülük - Mantıklılık) ilkesi, konu ile ilgili olmayan materyallerin öğretim tasarımı dışında tutulması ile öğrenmenin daha iyi gerçekleştirildiği düşüncesini içermektedir. Tutarlıık ilkesi, konu dışı materyallerin öğrencinin dikkatini dağıtacağı düşüncesiyle geliştirilmiştir (Mayer, 2001: 113). Konu ile ilgili olmayan sözcük ve seslerin, öğrenenin dikkatini dağıtmasına neden olduğu ve konuyu kavrama süresini uzattığı ifade edilmektedir. Bu ilke, uygulama tasarımında içerikle bağlantısı olmayan tasarım ögelerine (ses, metin, görsel öge, şekil, müzik vb.) yer verilmemesini gerekli kılar. (4) Biçim / Sıraya Koyma / Kanal Illkesi, çoklu ortam tasarım uygulamalarında tasarım ögelerinden sözcük (metin) ve animasyonun aynı anda sunulması yerine, sözlü anlatımların ve animasyonların birlikte yer alması ile öğrenmenin daha kalıcı hale getirildiğini içerir. Mayer'e göre, öğrenenler, ekranda yer alan sözcük ve animasyondan ziyade sözlü anlatım ve animasyonla daha iyi öğrenme yaşarlar (2001: 134, 184). Metin ve animasyonun aynı anda sunulması ile öğrenenin bilişsel sistemine hem resim hem yazı işlenir ve görsel sistemde aşırı yüke neden olur. Bu nedenle sözlü anlatımlı animasyon gösterimlerinde öncelikle sözcükler bireyin sözel kanalına girer ve öğrenen görsel kanalda resimleri işler (Kuzu, 2014: 15). (5) Gereksizlik / Aşırlık ilkesi, görsel öge ve seslendirilmiş metinlerin birlikte kullanıldığı tasarımlarla, ses, metin ve görsel ögenin üçünün birlikte kullanıldığı tasarımlara göre daha iyi öğrenme gerçekleştirilmesini kapsar. Mayer'in Bilişsel Yük Kuramına göre, bilişsel yüke aşırı yüklenmemek adına üç öğenin aynı anda kullanılmaması önerilir. Üç ögenin aynı anda kullanılmaması ile öğrenenler metinleri görsel ögelerle ilişkilendirirken metinlere daha fazla dikkat ederler. Gözleri metindeyken ekrandaki görsel ögeleri göremeyebilirler (Clark ve Mayer, 2003: 100). (6) Bireysel Farklılıklar İlkesi, tasarım etkisi, daha az bilgiye sahip öğrenenlerde daha çok bilgiye sahip öğrenenlerden daha fazladır (Mayer, 2001: 161). Söz konusu ilkeye göre, çoklu ortam tasarımı, öğretilen konu hakkında fazla bilgi sahibi olanlardan çok, az bilgi sahibi insanlar için daha etkili olduğunu içerir (Perkmen, 2009: 107). Mayer'e göre "konu hakkında ön bilgi sahibi olanlar önceki bilgilerini kullanarak yalnızca sözcüklerle sunulan sözel bilginin zihinsel modelini çok rahat çıkarabilirler". Konu hakkında bilgi sahibi olmayanlar ise, "zihinsel model oluşturmada güçlük çekerler". (Aktaran: Perkmen, 2011: 79). Bu ilke, çoklu ortam tasarımının hitap ettiği kişileri netleştirici niteliktedir. (7) Bölümlere Ayırma / Parçalara Bölme İlkesi, öğrenenlere sözlü anlatımlı bir animasyonu tek parça halinde uzun süreli izletmektense, bölümlere ve parçalara ayrılmış küçük boyutlu olarak sunmanın daha iyi bir öğrenme yaşatacağını içermektedir. Bilişsel yüke yüklenen bilginin kontrolünün 
kullanıcıya verildiği bu ilke ile öğrenen, çoklu ortam tasarımında yer alan sözlü anlatımlı animasyonları kısa bölümlere ayrılmış şekilde izleyebilir. (8) Sinyal illkesi, çoklu ortam tasarımında, içeriği destekleyici işaretlerin, yönlendirici metinlerin, dikkat çekici sinyallerin, açıklayııı bilgilerin, dikkat toplayıcı ve dolaşımı kolaylaştırıcı yönlendirmelerin ve metinlerin içermesi gerektiğini kapsamaktadır. Böylelikle öğrenenler daha nitelikli ve kalıcı bir öğrenme süreci yaşarlar. (9) Kişileştirme İlkesi ise, öğrenenlerin öğretim materyalinde yer alan metnin ya da seslendirmenin akademik bir dil yerine günlük bir dil kullanımı ile daha iyi öğrenme gerçekleştirileceğini içerir.

$\mathrm{Bu}$ özelliklerin yanında etkileşimli medya tasarımı, çoklu ortam uygulamalarında kullanıııların uygulama içerisindeki dolaşımını etkileyen ve bireysel etkinlik kazandıran önemli bir özellik barındıır. Ôyle ki etkileşim kavramı karşılıklı olarak etkileme anlamına gelen, elektronik yayımcılıkta da okuyucu ile yayımcı arasında bir bağ kuran, yayımcılığı tek yönlülükten çıkaran bir özellik olmuştur. Illetişimin tek taraflı bir olgu olmaması gerektiği gerçeğinden hareketle etkileşim, medya uygulamalarında ve çoklu ortam tasarımlarında kullanıcıyı etkinleştiren, uygulamayı yönlendirebilen, denetleyebilen ve içerisinde gezinebilen bir hale dönüştürmesi açısından söz konusu uygulamalarda önemli bir özellik olarak var olur. Gestalt ilkeleri ve Çoklu Ortam Tasarım İlkeleri gibi Görsel Tasarım İlkeleri de bütünsel anlamda tasarımın mesajının iletilmesini etkileyen ve bireyin algı ve bununla beraber öğrenme becerisini olumlu etkileyen özellikler barındırmaktadır. Öyle ki tasarımın görselleştirilmesi, ögelerin belirli biçimsel bir düzen ve bütünlük içerisinde bir araya getirilmesi sürecinde yaşanır. Bu bağlamda söz konusu görsel tasarım ilkelerine yer vermek yerinde olacaktır.

\section{Görsel Tasarım Ögeleri ve İlkeleri}

Görsel iletişim ve grafik tasarım, iletişim kavramıyla yakından ilişkilidir. Mesaj iletme kaygısıyla iletişimi sağlama görevi olan grafik tasarım, bireylerin görsel algı düzeyini etkileyerek görsel tasarım ögeleri aracılığıyla çevresi ile iletişime geçmesini sağlar. Öyle ki görsel iletişim ve tasarım kavramları bu açıdan değerlendirilebilir. İletişimi grafik tasarımın hayati ögesi olarak sayan E. Becer, “...grafik tasarımı bu denli ilginç, dinamik ve çağdaş kılan şey de iletişime yönelik olmasıdır" sözüyle belirtmektedir (2002: 34). Aynı şekilde tasarımcıların da güncel bilgiyi, çağdaş beğeni anlayışı içinde ve yine çağdaş araç ve gereçlerle sunmak zorunda olduğunu, böylelikle de yeni eğilimleri, teknolojik buluş ve yenilikleri izleyen kişiler olması gerektiğini ifade eder (Becer, 2002: 35). Çoklu ortam tasarımı, yeni medya uygulamaları, eğitimde teknoloji entegrasyonu ve yeni iletişim donanımlarının etkisiyle tasarımcıların, bireylerin görsel algı yetenek ve 
becerilerini etkileyen faktörleri göz önünde tutarak, öğrenme düzeylerini etkileyecek ilkelere sadık kalarak ve evrensel tasarım ilkeleri gözeterek ürünleri tasarlamaları gerekmektedir. Öyle ki evrensel tasarım ilkeleri, bir grafik tasarım ürünün niteliğine etki edecek ve hedefine ulaştıracak bir sürecin içeriğinde kullanılır. Çizgi, renk, ton, doku, biçim, ölçü ve yön bir grafik ürünün tasarımında kullanılan görsel ögeler olarak sıralanır. Bütünü oluşturan parçaların bütünsel anlamda algıyı yaratabilmesi açısından parçaların belirli kurallara göre düzenlenmesi gerekir. Bu ögeleri, etkili bir tasarım gerçekleştirebilmek için yerleştirme/biçimsel düzenleme, bütünsel anlamda algıyı yaratabilmesi ve mesajı iletebilmesi açısından önemlidir. Bunlar ise evrensel tasarım ilkeleri/görsel tasarım ilkeleri olarak nitelendirilir. Öyle ki, grafik tasarım evrensel bir dile sahip olma özelliği ile etkili bir iletişim ürünü geliştirebilen bir niteliktedir. Yararlanılan ilkeler, görsel algı ve işleme kuramı çerçevesinde anlamlanmakta ve denge, oran - orantı, hiyerarşi, görsel devamlılık, bütünlük, karşıtlık (zıtık), yakınlık, hizalama, ritim ve vurgu kavramları üzerine şekillenmektedir (Ketenci ve Bilgili, 2006: 282), (Becer, 2002: 56-74). Grafik tasarımcılara göre söz konusu tasarım ögeleri farklı şekillerde sıralanmaktadır. Bunlardan biri, boşluk, birlik (bütünlük), sayfa düzenlemesi (inşaası) ve yazı olarak tanımlanmakta (White, 2011), bir diğeri de biçim ve boşluk, renk temelleri, yazı karakterinin seçimi ve kullanımı, görsel öge ve bu ögelerin bir arada kullanılması olarak (Samara, 2007) ifade edilmektedir. Alexander W. White, yedi tane temel tasarım bileşeni olduğunu söylemekte, bunları boşluk, birlik ve Gestalt, nokta, çizgi ve düzlem, büyüklük ve hâkimiyet, hiyerarşi, denge ve renk olarak ifade etmektedir (2011: 81). Bütün tasarım ögeleri birbirleriyle ilişkili olarak nitelik geliştirir. Örneğin, tasarımda kullanılan tüm ögelerin düzenlenmesi, tasarımda bütünlüğü (birliği) var eder. Baskınlık özelliği de, diğer nesnelerin büyüklük, konum, renk, biçim ve düzlemiyle ilgili olarak geliştirilir. Eşit ölçülerdeki ögelerin bir arada kullanılmasıyla tasarımda vurgu noktası yaratılamaması durumunun hiyerarşi özelliği ile ilişkilendirilebildiği gibi. $\mathrm{Bu}$ nedenle her bir ögenin özellikleri bir diğerine göre şekillendirilerek etkili bir tasarım gerçekleştirilebileceği söylenebilir. Ulaşılabilirlik, estetik düzey, kullanılabilirlik, uygunluk-uyumluluk, bilişsel çelişki - uyumsuzluk, renk, tutarlılık, süreklilik, sınırlama, yakınsama - benzeşme, figür - zemin ilişkisi, biçim işlevi takip eder prensibi, boşluk - doluluk, yoğunlaşma, görünürlük, benzerlik, yönelim ve okunaklıık söz konusu ilkelerin devamı niteliğinde biçimin işlevselliğini destekleyici düzenleme kuralları olarak sayılabilir (Lidwell, Holden and Butler, 2010). Çoklu ortam ilkelerinden Bütünlük İlkesi'ne göre, birbiriyle ilişkili olmayan ögelerin kullanılmasıyla tasarımın bütünlüğünün bozulması durumu ile içerikte dikkat çekilmesi ve vurgulanması gereken ögenin diğer ögelere göre daha belirgin büyüklükte, 
dokuda ve renkte kullanılmasıyla görsel tasarım ilkelerinden Vurgu ilkesi ilişkilendirilebilir. Bu şekilde izleyicilerin dikkatlerini çekmeleri istenen odak noktası belirginleştirilmekte ve esas ögenin diğerlerinin önüne geçmesi sağlanmaktadır. Baskınlık, hâkimiyet, hiyerarşi ve vurgu özellikleriyle bu durum paralel anlamlıdır.

$\mathrm{Bu}$ ilkeler, tasarım ürünleri geliştirilirken gözetilmekte, yapı ögelerinin inşası, konumlandırılması ve bireysel üslup kazandırılması sürecin sonucunu hazırlamaktadır. Hem işlevsel hem de biçimsel anlamda nitelikli bir tasarım ürünü geliştirebilmek, anlamsal ve biçimsel ilkeleri bilmek ve bilinçli uygulamak ile sağlanabilir.

\section{Çoklu Ortam Uygulamalarından Örnek İncelemeleri}

Bu aşamada, çoklu ortam tasarımlarından eğitici ve öğretici e-kitap, oyun, etkinlik uygulamaları, bilgilendirici yönlendirici grafikler, etkileşimli medya uygulamaları söz konusu ilkeler çerçevesinde değerlendirilebilir. Uygulamalardan eğlenerek öğrenme deneyimi olan PBS KIDS adlı oyun şirketinin geliştirdiği peg-cat, etkileşimli medya uygulamalarıdır. Pegcat, etkileşimli eğitsel-öğretici etkinlik uygulaması olarak tanımlanabilir. Bunlardan biri Peg's Pizza Place isimliöğreticibir oyun/etkinlikuygulamasıdır (Görsel 1). Adı geçen şirketin geliştirdiği uygulamalar, bir ekip çalışması projeleridir. Oyun geliştiriciler, yapımcı, müzik ve ses tasarımcıları, grafik tasarımcılar, sanat ve tasarım yönetmenleri, animasyon yapımcıları, yaratıcı yönetmenler, eğitim danışmanları, psikolog ve yazılımcılar bu geniş ekibin üyeleridir. Peg's Pizza Place isimli oyun, 3-5 yaş arası okulöncesi dönemdeki çocuklara hitap etmektedir. Peg ve Kedi, eğlenceli etkinlik olan ve matematik temelli macera serilerinin kahramanlarıdır. Uygulama öğretme, pekiştirme ve kavratma üzerine kurgulanmıştır. Amaç, söz konusu yaş aralığındaki çocuklara matematiği eğlenceli ve anlaşılır bir şekilde öğretmektir. Etkinlik uygulamasında öğrenenden (çocuktan) bir pizza yapması beklenmektedir. Çocuk, etkileşimli ögeler olan pizza malzemelerini tut-sürükle-bırak yöntemiyle ekranda yer alan boş pizza hamuru üzerine yerleştirmekte, kaç tane koyması gerektiği ses veya yazı uyaranlarıyla belirtilmektedir. Bu şekilde sayma becerisi kazanmakta, sayıları pekiştirmekte ve hem görsel öge ile hem de metin yardımıyla öğrenme eylemi gerçekleştirilmektedir. 


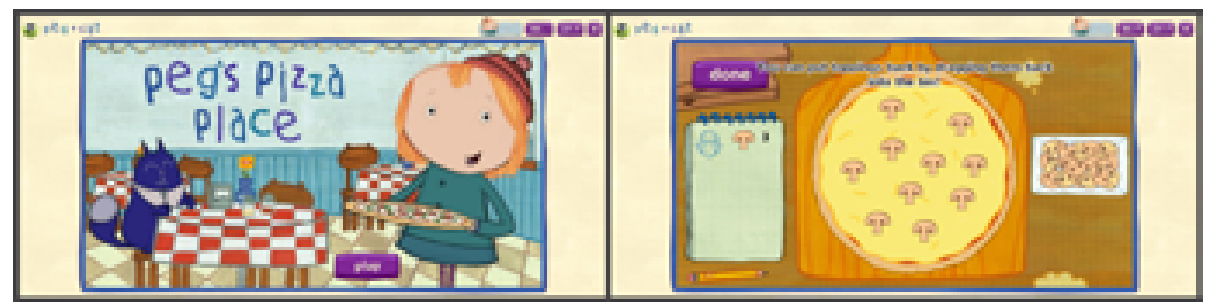

Görsel I: Jennifer Oxley, Billy Oronson 20I I, Peg'in Pizza Evi / Peg's Pizza Place ${ }^{2}$

Görsel öge ve sözcüklerin bir arada kullanılmasıyla Mayer'in Çoklu Ortam İlkesi, birbirleri ile ilişkili görsel öge ve sözcüklerin aynı ekranda yer almasıyla Birliktelik Illkesi, yalın ve anlaşılır tasarım ve kompozisyonunun, konu ile ilgili ögelerin sayfada (öğretim materyalinde) yer verilmemesi özelliği ile Tutarlılık İlkesi, sözlü anlatım ile görsel ögelerin bir arada kullanılmasıyla (yazı ögesinin isteğe bağlı görüntülenebilir olması) Biçim İlkesi'ne uyulduğu görülmektedir. Öğrenmeyi ve algıyı kolaylaştırıcı özelliklerin kullanılmasıyla, sözkonusuöğretim materyaliniteliğinin arttırıldığısöylenebilir. TheHighlight Zone adlı eğitsel etkinlik uygulamasında da (Görsel 2), Mayer'in Çoklu Ortam Tasarım Illkeleri gözetilmiş, geometrik şekilleri kavratmaya yönelik söz konusu çoklu ortam tasarımında öğrenmeyi kolaylaştıııcı yapı örüntüsü ile görsel öge, ses, sözlü anlatım, yazı ögesi ve renk vurguları Peg's Pizza Place adlı eğitici uygulamada olduğu gibi tasarlanmıştır. Bu şekilde çocuğa çalışan belleğinin öğrenmeye etkisi gözetilerek bilgi aktarılmaktadır. Görsel ögelerin kurgusu yapılırken ve görsel alfabe geliştirilirken temel tasarım ilkeleri, ortaya konulan Gestalt kuramının nesnel kuralları olarak ifade edilir (Bayraktar ve diğerleri, 2012: 13). Öyle ki, tasarım eğitimi verilen kurumlarda da bu kuralları çeşitli öge, araç ve ortamlarda kullanabilme becerisi kazandırımaktadır. Tasarım ögelerinin kullanımı, diğer ögelerle olan birlikteliği ve etkisi düşünülerek yerleştirilir. The Highlight Zone adlı uygulamada da geometrik şekillerin birbirleriyle olan ilişkisi, mesafe, renk, doku ve büyüklük farklııkları yaratılarak konumlandırılmıştır. Bu etkileşimli medya uygulaması ile bireylerin dikkatleri amaçlanan vurgu noktasında tutulmaktadır. Aynı zamanda öğrenmeyi kolaylaştırıcı nesnelere biçimsel farklılıkların kazandırıldığı ve konumlandırmalar yapıldığı görülmektedir.

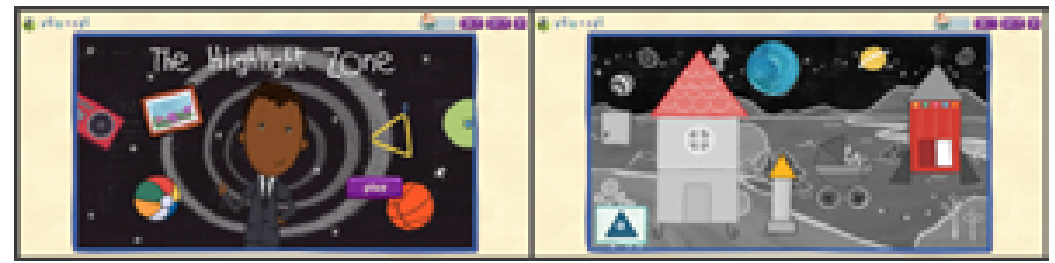

Görsel 2: Jennifer Oxley, Billy Oronson (Pbs Kids) 20II, Vurgu Bölgesi / The Highlight Zone. ${ }^{3}$

${ }^{2}$ Oxley, J., Oronson, B. (20II). Peg's Pizza Place, Web: http://pbskids.org/peg/games/pizza-place adresinden 07 Mayıs 2015'te alınmıştır.

${ }^{3}$ Oxley, J., Oronson, B. (20II). The Highlight Zone, Web: http://pbskids.org/peg/games/highlight-zone adresinden 07 Mayıs 2015'te alınmıştır. 
iPad için özel olarak hazırlanmış bir etkileşimli çocuk hikâye kitabı olan Nedi the Yeti (Görsel 3), bir oyun havasında 2 ve üzeri yaş çocuklara yönelik eğitici ve eğlendirici bir hikâyeden oluşur. İlgi çekici yalın resimleme dili, eğlenceli ve etkileşimli hayvan figürleri ile çocuklara renkleri, hayvanları ve numaraları öğretme görevi üstlenir.

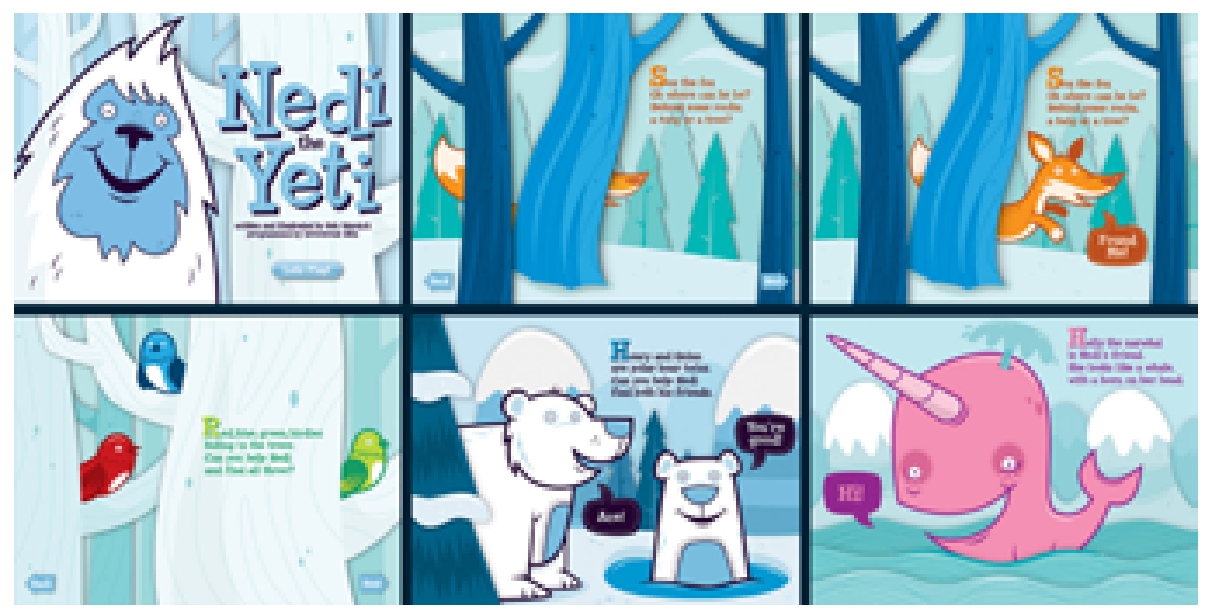

Görsel 3: Rob Warnick, Lee Calloway 20I I, Nedi Yeti / Nedi the Yeti. ${ }^{4}$

Yazarı ve çizeri Rob Warnick olan ve uygulamanın programcısı Lee Calloway olan bu kitap ile birden fazla duyuya aynı anda hitap eden bir yaklaşım vurgulanmıştır. Hikâye kahramanı Nedi, saklambaç oynayarak arkadaşlarını aramaktadır. Bu sırada renk, nesne, sayı, biçim kavramları iletilmekte, kullanıılar renkler ile hayvanları eşleştirmektedir. Ses ve etkileşim bu kitabı eğlenceli yapan uyaranlardır. Çoklu Ortam Illkeleri gözetilerek hazırlanan bu uygulamanın, nitelikli etkileşimli e-kitaplar arasında yer aldığı söylenebilir. Uygulama görsel tasarım ilkeleri açısından değerlendirildiğinde, sahne tasarımlarında kullanılan vurgu noktaları, renk, doku ve büyüklük farklılıklarıyla belirginleştirilmiştir. "Beni bul" diyen tilkinin mavi bir atmosferde karşıt renk olan turuncu renk ile işaretlenmesi gibi. Sahne tasarımlarda görsel ögelerin bütünlük içerisinde ele alınması ve tasarımlarda devamlılığı sağlayacak biçimsel düzenleme anlayışının hâkimiyeti, uygulamanın niteliğini arttıran özellikler olarak sıralanabilir.

Bir diğer örnek, Paperplane şirketi tarafından piyasaya sürülen Monkeys in My Head adlı etkileşimli elektronik çocuk kitabıdır. Monkeys in My Head, Pirouette isimli küçük bir kız çocuğunun ve onun kafasının içindeki maymunların hikâyesini konu almaktadır (Görsel 4). 4 yaş ve üzeri çocuklar

\footnotetext{
${ }^{4}$ Warnick, R., Calloway, L. (20I I). Nedi the Yeti, Web: http://www.bestinteractiveebooks. com/2012/03/nedi-the-yeti/ adresinden 15 Mayıs 2015'te alınmıştır.
} 
için tasarlanmış bu kitap, özgün hikâyesi ve resimlemesi, etkileşimli sayfaları ve ögeleri ile iPad uygulaması olarak geliştirilmiştir.

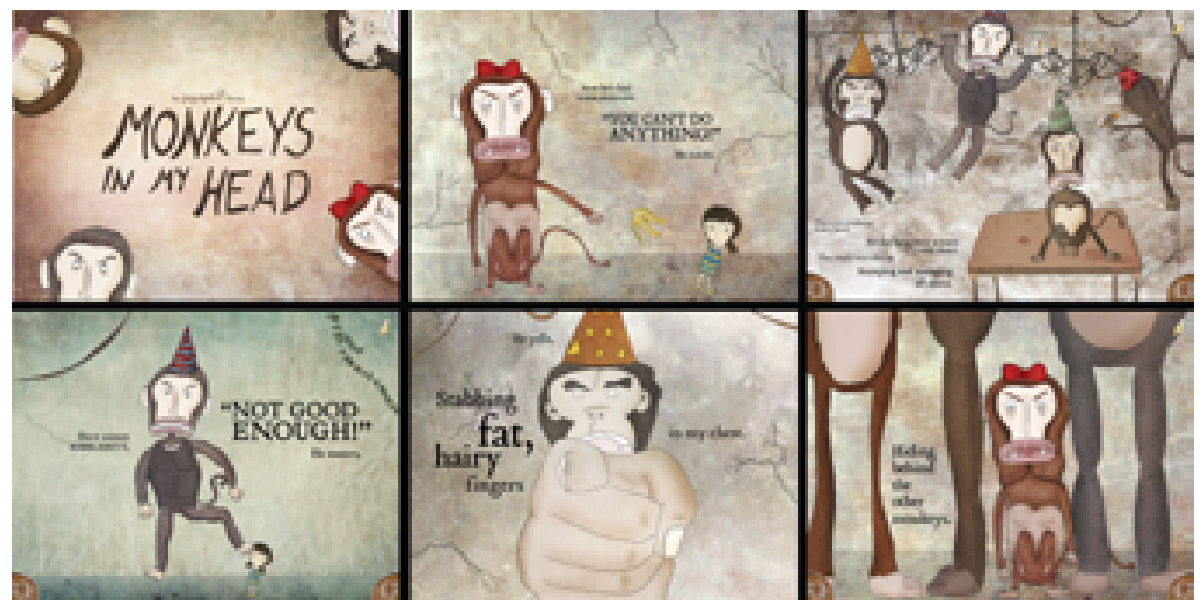

Görsel 4: Paperplane Pilots Pte Ltd., 20I2, Kafamın İ̧cindeki Maymunlar / Monkeys in My Head. ${ }^{5}$

Kitabın her sayfasında hareket ettirilebilen görüntüler, sayfalar arası geçişin hızlı film şeridi özelliğinde olması, özgün resimleme dili, seslendirme, müzik ve ses efektleriyle dolgunlaştırılmış bir e-kitap uygulaması olmasını sağlamıştır. Her insanın zihninde yaşattığı canlılarla baş etmenin yollarını öğreten bu kitap, sözcük, kavram, şekil ve ses arasındaki ilişkiyi netleştirmektedir. Uygulama, birbirleri ile ilişkili sözcük ve görüntülerin bir arada kullanılması, görsel ögeler ile sesli anlatımların bütünleştirilmesiyle çoklu ortam tasarım ilkelerine, dengeli kompozisyon anlayışı, görsel hiyerarşi, biçimsel bütünlük ve vurgulama özellikleriyle de görsel tasarım ilkelerine uymaktadır.

İnsanlarda öğrenme deneyiminin nitelikli gerçekleştirilebilmesi adına Mayer'in geliştirdiği ilkeler, çoklu ortamla öğrenme deneyiminin nitelikli, akılda kalıcı ve sorunsuz yaşanması adına izlenmesi gereken bir süreci kapsar. Tıpkı tasarım ilkelerinin nitelikli ve amacına uygun grafik ürünlerin oluşturulması için geliştirilmesi ve kullanılması gibi. Görsel öge ve sözcük arasındaki bağlantıların kurulabilmesinde etken olan bu ilkeler, görsel ögelerin düzenlenmesini, görsel ögelerin çalışan bellekte yazı ögesi ile eşleşmesini, sözcüklerin çalışan bellekte kolaylıkla işlenmesini, sözlü ve görsel ögelerin bilgi metinleriyle bütünleştirilmesini kullanılır. Yapılan

\footnotetext{
${ }^{5}$ Paperplane Pilots Pte Ltd. (20I2). Monkeys in My Head, Web: http://www.paperplaneco.com/\#/0/4 adresinden 15 Mayıs 2015'te alınmıştır.
} 
çalışmalarda, kurgu, analiz, hedef, tasarım, yazılım geliştirme, uygulama, kompozisyon, kullanılabilirlik testi ve değerlendirme olgusu bir öğretim tasarımının gerçekleştirilmesi kapsamında çoklu ortam projesi hazırlama aşamaları olarak sayılabilir. Çoklu ortam tasarım ilkeleri de bu anlamda söz konusu sürecin alt yapısını oluşturan önemli bir aşamadır. Tasarım sürecinin görsel tasarım ilkeleriyle işlenerek tamamlanması ise tasarım ürünlerinin ve medya uygulamalarının niteliğini arttıracağı yönündedir.

\section{Sonuç}

Çoklu ortam tasarım uygulamaları, öğrencinin etkinleştirildiği ve kullanıcı kontrolününverildiğibiröğretimtasarımıalanuygulamasıolaraktanımlandığı şu günlerde, öğrenme materyalleri taşıdıkları anlamları ve içerikleriyle öğrenenlere bilgi edinme sorumluluğu yüklemektedir. Uygulamaların bireyselleştirilmesi, uygulamalara eklenen etkileşimli ögelerin kullanıcı kontrollü ilerlemesi, öğrenenlerin kullanıcı olarak etkinleştirilmesi bu şekilde açıklanabilir. Öğrenenin söz konusu öğretim materyalinin taşıdığı anlamı anlamlandırabilmesi ise öğrenenin onu nasıl algıladığı ileilişkilidir. Bu nedenle algı oluşturma, mesajı taşıdığı anlamıyla iletebilme, algıyı yönlendirebilme bu makale kapsamında gerek Gestalt illkeleri gerek Çoklu Ortam Tasarım ilkeleri ile desteklenmiştir. Bu nedenle, algıyı oluşturabilme, öğrenmeyi kolaylaştırma, anlamı çıkarabilme, mesajı iletebilme anlamında tasarımda kullanılan tasarım ögelerinin (görsel ve sözel ögelerin) kişinin öğrenmesini kolaylaştırdığı gerçeği düşünülerek tasarımın gerçekleştirilmesi bu yazının temel sorunsalıdır. Söz konusu özelliklerden hareketle nitelikli eğitsel çoklu ortam uygulamaları örnekler üzerinden değerlendirilmiştir. Öyle ki tasarımcıların bir kitabın içeriğini bilmeden kapağını tasarlamasının yanlış bir yöntem olduğu bir gerçekse, çoklu ortamda öğrenme ilkeleri hakkında bilgi sahibi olmadan üretilen çoklu ortam tasarımları da, yalnızca tasarlanan ürün olarak adlandırılabilir. Keza bir tasarım ürününün işlevsel olması, ulaşılabilir olması, işler, kullanılabilir ve algılanabilir olması niteliğini destekler özellikler olarak görülmektedir. Bu makale kapsamında, algıyı yönlendirici ve öğrenmeyi kolaylaştırıcı çoklu ortam özellikleri incelenmekte, çoklu ortam tasarım ilkeleri ve görsel tasarım ilkeleri dâhilinde örnek değerlendirmeleri yapılmakta, uygulamaların nitelikli bir süreç içerisinde tamamlanması ve değerlendirilmesi için sürecin programlanması önerilmektedir. Genel değerlendirme çerçevesinde görsel tasarım ilkeleri ve çoklu ortam tasarım ilkeleri, etkileşimli medya uygulamalarının nitelikli ürün geliştirme sürecini tanımlayan aşamalar olduğu sonucuna ulaşılmaktadır. Öyle ki, etkileşimli çoklu ortam tasarım uygulamaları, disiplinler arası bir süreç dâhilinde üretilmektedir. Bu nedenle bu süreç çeşitli alan uzmanlarının işbirliği ile biçim bulmaktadır. Ekibin, alanında uzman/yetkin kişilerden oluşturulması 
ve etkileşim özelliği ile öğretim ortamlarında okuyucuya kullanıcı rolünün kazandırılması (etkinliğinin artıııması), öğretim ortamlarında işlevsel yönden güçlü öğretim materyallerinin geliştirilmesini etkilemektedir. Söz konusu materyallerin, görsel tasarım ilkeleri ve görsel ve işitsel ögelerin aynı anda iletildiği ortamlar olan etkileşimli medya çerçevesinde çoklu ortam tasarım ilkeleri gözetilerek hazırlanması ise tasarım geliştirme sürecini biçimlendirdiği ve öğretim materyalinin niteliğini etkilediği sonucuna varılmaktadır. 


\section{Kaynakça}

Akbulut, Y. (20I4). Bilişsel Yük Kuramı ve Çoklu Ortam Tasarımı. Dursun, Ö.Ö. ve Odabaşı, F.H. (Ed.). Çoklu Ortam Tasarımı. Ankara: Pegem Akademi Yayınları.

Bayraktar, N., Tamer Görer, N., Tekel, A., Gürer, N., Kızıltaş Ceylan, A. ve Köroğlu Armatlı, B. (20I2). Görsel Eğitimde Yaratıcılık ve Temel Tasarım. (I.Baskı). Ankara: Nobel Akademik Yayıncilık.

Becer, E. (2002). Iletişim ve Grafik Tasarım. Ankara: Dost Kitabevi Yayınları.

Clark, R.C. ve Mayer, R.E. (2003). E-learning and the Science of Instruction. Proven Guidelines for Consumers and Designers of Multimedia Learning. San Francisco: Pfeiffer.

Cüceloğlu, D. (20/3). Insan ve Davranışı. (27.Baskı). İstanbul: Remzi Kitabevi.

Fer, S. (20I I). Öğretim Tasarımı. (2.Baskı). Ankara: Anı Yayıncılık.

Gülbahar, Y. (20I2). E-öğrenme. Ankara: Pegem Akademi Yayınları.

Ketenci, H.F. ve Bilgili, C. (2006). Yongaların 10000 Yıllık Gizemli Dansı Görsel Illetişim ve Grafik Tasarımı. İstanbul: Beta Basım A.Ş.

Kuzu, A. (20/4). Çoklu Ortam Uygulamalarının Kuramsal Temelleri. Dursun, Ö.Ö. ve Odabaşı, F.H. (Ed.). Çoklu Ortam Tasarımı. Ankara: Pegem Akademi Yayınları.

Lidwell, W., Holden, K. and Butler, J. (2010). Universal Principles of Design. Singapore: Rockport Publishers.

Mayer, R. E. (200I). Multimedia Learning. Cambridge: Cambridge University Press.

Perkmen, S. ve Ayten, Ö. (2009). Multimedya ve Görsel Tasarım. İstanbul: Profil Yayıncılık.

Perkmen, S. (20I I). Öğrenmeye Bilişsel Bakış ve Çoklu Ortam (Multimedya). Perkmen, S. ve Tezci. E. (Ed.). Eğitimde Teknoloji Entegrasyonu. Ankara: Pegem Akademi.

Samara, T. (2007). Design Elements A Graphic Style Manual. United States of America: Rockport Publishers.

Senemoğlu, N. (20I0). Gelişim Öğrenme ve Öğretim Kuramdan Uygulamaya. (I8.Baskı). Ankara: Pegem Akademi.

Tezci, E. (20I I). Öğretim Materyallerinin Tasarımı. Perkmen, S. ve Tezci, E. (Ed.). Eğitimde Teknoloji Entegrasyonu Materyal Geliştirme ve Çoklu Ortam Tasarımı. Ankara: Pegem Akademi. 
Tuna, S. (2009). Görsel Algı ve Imgelem Gücü. Alakuş, A.O. ve Mercin, L. (Ed.). Sanat Eğitimi ve Görsel Sanatlar Öğretimi. Ankara: Pegem Akademi.

Uçar, T. F. (2004). Görsel İletişim ve Grafik Tasarım. İstanbul: Inkılap Kitabevi.

White, A.W. (20I I). The Elements of Graphic Design. (2.Baskı). New York: Allworth Press.

\section{Internet Kaynakları}

Internet: Levie, W.H., Lentz, R. (1982). Effects of Text Illustrations: A Review of Research. ECTJ, 30(4), s. (195-232), Web: http://link.springer.com/ article/I0.1007\%2FBF02765 I84\#page- adresinden 05 Mayıs 2015'te alınmıştır.

Internet: Oxley, J., Oronson, B. (20II). Peg's Pizza Place, Web: http://pbskids.org/peg/ games/pizza-place adresinden 07 Mayıs 2015'te alınmıştır.

Internet: Oxley, J., Oronson, B. (20II). The Highlight Zone, Web: http://pbskids.org/peg/ games/highlight-zone adresinden 07 Mayıs 2015'te alınmıştır.

Internet: Paperplane Pilots Pte Ltd. (20/2). Monkeys in My Head, Web: http://www. paperplaneco.com/\#/0/4 adresinden 15 Mayıs 2015'te alınmıştır.

Internet: Warnick, R., Calloway, L. (20II). Nedi the Yeti, Web: http://www. bestinteractiveebooks.com/20 I2/03/nedi-the-yeti/ adresinden I5 Mayıs 20 I 5 'te alınmıştır.

\section{Görsel Kaynakları}

Görsel I: Jennifer Oxley, Billy Oronson 20 I I, Peg'in Pizza Evi / Peg’s Pizza Place.

Erişim: 07 Mayıs 2015, http://pbskids.org/peg/games/pizza-place

Görsel 2: Jennifer Oxley, Billy Oronson (Pbs Kids) 20I I, Vurgu Bölgesi / The Highlight Zone. Erişim: 07 Mayıs 2015, http://pbskids.org/peg/games/highlight-zone

Görsel 3: Rob Warnick, Lee Calloway 20I I, Nedi Yeti / Nedi the Yeti. Erişim: I5 Mayıs 2015, http://www.bestinteractiveebooks.com/2012/03/nedi-the-yeti/

Görsel 4: Paperplane Pilots Pte Ltd., 2012, Kafamın İçindeki Maymunlar / Monkeys in My Head. Erişim: I5 Mayıs 2015, http://www.paperplaneco.com/\#/0/4 
